\title{
In a Time of Global Upheaval- Humanistic Management Thinking Needed More Than Ever
}

\author{
Michael Pirson ${ }^{1}$
}

Published online: 10 March 2017

(C) Springer International Publishing 2017

\section{Introduction}

In uncertain times, we are happy to announce the publication of the second volume of the Humanistic Management Journal. While it is sometimes easy to despair and question the value of our collective work, we can benefit from knowing that despite historical hiccups, good and valid ideas are stronger than emotional and political fads. Our journal was established in a time when the failures and cracks of the pervasive "economistic" view of the world have become very evident. It is our hope that the basic values of freedom and dignity can be part of organizing theory and practice much more fundamentally than they had been in the past (Pirson 2016).

The past, though, seems to have returned in the form of tribalist thinking and action. The notions of tribe, tradition, and religion again are viewed as opposed to the concepts of individualism, universalism, reason, and science. The humanist management network has aimed to reconcile those notions, the past and the future. Yet, the political Zeitgeist is seemingly working against humanistic principles. If history is a guide the return to emotionbased tribalism will create more upheaval. We, therefore, need to speak up as principled, public intellectuals and be ready to provide acceptable alternative roadmaps for organizations and society now and in the foreseeable future.

When the intellectual founding fathers of Neoliberalism met at Mont Pelerin in 1947, they could only agree on one thing: they wanted to create a political and economic system that protected dignity and individual freedom (Lovins 2016; Waddock 2016). Since then, because of the technocratic approach to human systems design the notion of dignity as that which has intrinsic value fell by the wayside. Freedom also, has been mostly understood as economic freedom or as what our colleague Claus Dierksmeier labels quantitative freedom (Dierksmeier and Pirson 2010). The humanistic community is therefore called upon to conceptualize more intentionally a humanistic system of governance that protects dignity and freedom while not undermining the human need for community on a healthy planet.

Michael Pirson

pirson@fordham.edu

1 Fordham University, New York City, NY, USA 


\section{Overview of Contributions to this Issue}

In this second issue, we are excited to present several papers that go to the core of many conceptual debates. In the original paper section, we are happy to provide two papers that challenge the economistic conception of the theory of the firm. The noted Chicago economist Luigi Zingales challenged the scholarly community to present alternative conceptions of the firm long ago - very little progress seems to have been made. We are therefore glad to publish Shann Turnbull's article that grounds an alternative theory of the firm in the natural sciences.

Using the perspective of cybernetics, the science of control and communication, Turnbull (2017) adopts an implicit model of human nature that accepts physiological and neurological limitations to receive, store, process and act upon information to coordinate their activities. Rather than following the traditional argument of transaction costs for firms to exist, he introduces Transaction Byte Analysis to argue that the exchanges of data and information in a structured community of people providing for feedback loops is a better guide for corporate governance.

In a second paper, JC Spender (2017) also builds on the critique of the economistic theory of the firm. Spender suggests that without a viable theory of the firm management educators have no sound basis for teaching. He argues that economists have not yet answered Coase's questions and the management discipline seems to ignore the implications. Spender draws on Frank Knight's intuition to introduce risk and uncertainty into an adequate understanding of organizing firms. That introduction, however, poses many challenges for educators who mostly provide comforting theories of precision (such as profit maximization as ultimate goal of the firm, which implies certainty about assessing which pathway will do exactly that.) Spender then explores Herbert Simon's observations for designing business schools and explores implications for alternative pedagogy.

One of the more recent emerging challenges to the traditional theory of the firm positing shareholder value maximization has been social entrepreneurship. Social enterprises by their most generic definition aim to solve social problems profitably, ultimately aiming to create social rather than financial value maximization. Social Entrepreneurs may also, as suggested by some, aim to balance rather than maximize their outputs. The research presented by Andres Chinchilla and Mayte Garcia (2017) suggests that in the process of doing so mindfulness may play a significant role in spotting opportunities for shared value creation. In their empirical assessment, the authors provide preliminary evidence that the level of mindfulness does play a role in the intention to create a social entrepreneurial venture. We publish this research because we hope more empirical work can build on these preliminary findings.

In a fourth original paper, a group of researchers of the poverty research group at Massey University, New Zealand explore humanistic management and its related policy dimensions (Carr et al. 2017). Specifically, Stuart Carr, Jane Parker, James Arrowsmith, Jarrod Haar, and Harvey Jones explore the question of a living wage. They suggest that the balance between employee pay and human thriving remains theoretically and empirically under-explored especially at the lower-end of the wage and income spectrum. The existing theories such as Poverty Trap theory and the Law of Diminishing Returns offer seemingly contradictory predictions of the relationship between thriving and wages. In their exploratory study they test these competing theories by relating hourly wage rates to thriving as measured by sense of (i) work happiness (job satisfaction, empowerment, and pride), (ii) well-being (mental and physical health, participation in community life, life satisfaction); and (iii) wage fairness (compared to upper management, reciprocity for the job). They find evidence that the relationship 
between pay and well-being are statistically significant, but non-linear. They also find that there is a significant impact of a living-wage on pay justice.

Finally, we are very pleased to publish Jeffrey Sachs' Humanistic Management Honorary Lecture. Jeff Sachs was awarded the Humanistic Management Lifetime Achievement Award at our 4th Annual Humanistic Management Conference at the Global Ethic Institute in Tuebingen, Germany, October 14th, 2016. His lecture provides a thorough overview of the history of globalization and points out the trends which will influence current business and political strategies. He points to the challenges for humanistically minded scholars, practitioners and policy makers and suggests that the Sustainable Development Goals of the United Nations provide a good universalist, anti-tribalist, blueprint for collective action (Sachs 2017).

\section{Outlook}

We are living in a global world, and this planet is the only home we know. We as scholars have a duty to recognize our responsibility to organize ourselves, our relationships, and our institutions in a manner that can uphold freedom and human dignity for all and contribute to a world where everyone can flourish.

This worldview is highly contested not only but also because the economic order has been destructive to the well-being of all. It has instead served a moneyed elite which has irresponsibly and psychopathically acquired wealth to their own benefit. This trend seems only to be worsening under current political leadership. All the more, it is important to prepare alternative blueprints for an economy that works for $100 \%$ of humanity. Humanistic management is a framework for such organizing within an economic system that is life-conducive or as Hunter Lovins (2016) says "in service to life". We invite everyone so inclined to collaborate and submit their research.

We hope you like the current issue and we are also optimistic to receiving your best work soon.

\section{References}

Carr, S., J. Parker, J. Arrowsmith, J. Harr, and H. Jones. 2017. Humanistic management and living wages: a case of compelling connections? Humanistic Management Journal 2(1). doi:10.1007/s41463-016-0013-3.

Chinchilla, A., and M. Garcia. 2017. Social entrepreneurship intention: mindfulness towards a duality of objectives. Humanistic Management Journal 2 (1): 1-10.

Dierksmeier, C., and M. Pirson. 2010. Freedom and the modern corporation. Philosophy of Management (formerly Reason in Practice) 9 (3): 5-25. doi:10.5840/pom2010932.

Lovins, H. 2016. Needed: a better story. Humanistic Management Journal 1 (1): 75-90.

Pirson, M. 2016. Editorial: welcome to the humanistic management journal. Humanistic Management Journal 1 (1): $1-7$.

Sachs, J. 2017. Globalization - in the name of which freedom? Humanistic Management Journal 2(1).

Spender, J. 2017. BSchools and their business models. Humanistic Management Journal 2 (1): 1-18. doi:10.1007/s41463-016-0016-0.

Turnbull, S. 2017. Grounding a theory of firms in the natural sciences. Humanistic Management Journal 2(1).

Waddock, S. 2016. Foundational memes for a new narrative about the role of business in society. Humanistic Management Journal 1 (1): 91-105. 